\title{
Gut luminal endogenous protein: Implications for the determination of ileal amino acid digestibility in humans
}

\author{
Paul J. Moughan* and Shane M. Rutherfurd \\ Riddet Institute, Private Bag 11-222, Massey University, Palmerston North, New Zealand
}

(Submitted 26 July 2011 - Final revision received 4 October 2011 - Accepted 14 November 2011)

\begin{abstract}
The true ileal digestibility assay provides the most informative measure of digestibility to assess bioavailability of amino acids in foods for humans. To determine 'true' estimates of ileal amino acid digestibility, requires that endogenous amino acids present in digesta at the terminal ileum be quantified. The amounts of endogenous amino acids in ileal digesta can be determined after feeding an animal or human a protein-free diet (traditional approach) or by various methods after giving a protein-containing diet. When the protein-free method has been applied with adult human subjects an overall mean value (three separate studies) for endogenous ileal nitrogen flow of $800 \mathrm{mg}$ $\mathrm{N} / \mathrm{d}$ has been reported. This value is considerably lower than a comparable value obtained after feeding protein of $1852 \mathrm{mg} \mathrm{N} / \mathrm{d}$ (mean of four separate studies), and thus endogenous ileal $\mathrm{N}$ and amino acids should be measured under conditions of protein alimentation. There is some confusion concerning the terminology used to define digestibility, with the term "true" digestibility having different adopted meanings. Here, true amino acid digestibility is defined as apparent amino acid digestibility corrected for the basal amino acid losses determined after giving either a protein-free or a protein-containing diet. Basal losses should be determined at a defined dry-matter and protein intake. The protein-free diet approach to determining endogenous amino acids is considered unphysiological and basal losses refer to ileal endogenous amino acid flows associated with digesta dry-matter flow, and not including "specific" effects of dietary factors such as non starch polysaccharides and anti nutritional factors. Arguments are advanced that the enzyme hydrolysed protein/ultra filtration method may be suitable for routine application with a cannulated pig model, to obtain physiologically-valid basal estimates of ileal endogenous amino acids to allow calculation of true ileal amino acid digestibility in the pig, and then prediction (via statistical relationships) of true coefficients of amino acid digestibility in humans.
\end{abstract}

\section{Key words: Ileal digestibility: Human: Protein: Amino acids: Endogenous protein}

In simple-stomached species of animal in general, numerous studies have demonstrated that ileal digestibilities of most amino acids are lower than corresponding digestibilities determined over the entire digestive tract (faecal digestibility). This implies a net microbial degradation of most amino acids in the large intestine, as it appears that amino acids, as such, are not absorbed to any meaningful extent across the adult large bowel $^{(1)}$. For some amino acids (especially methionine) in some foods, however, net microbial synthesis occurs in the hindgut. In either case faecal amino acid digestibility values are subject to interference from hind-gut microbial metabolism and may be misleading. Adequate comparative ileal/faecal amino acid digestibility data for humans are lacking, but from the limited information that is available, it would appear that faecal estimates of amino acid digestibility are different from and are usually higher than their ileal counterparts ${ }^{(2)}$. Data in the literature on faecal and ileal amino acid digestibility for humans, generally pertain to highly-refined, high-quality proteins and greater ileo-faecal amino acid digestibility differences would be expected for less-refined foods and poorer quality proteins.

Several studies have been conducted with the growing pig, to evaluate the accuracy of ileal amino acid digestibility values for determining the extent of amino acid uptake from the gut lumen $^{(3,4,5)}$ and the ileal measure is well accepted as the method of choice for determining protein and amino acid digestibility in simple-stomached mammals generally. Consequently, this contribution focuses on luminal endogenous (of body origin) protein in the upper digestive tract (mouth to ileum) and its significance for the determination of ileal amino acid digestibility. A suggested approach for routinely determining true ileal amino acid digestibility values in protein sources for humans is outlined.

\section{Sites and Sources of Endogenous Protein}

During the digestion of food, large amounts of various proteins and nitrogen-containing materials originating from the 
body itself are voided into the lumen of the digestive tract. Collectively this material is referred to as the endogenous nitrogen, and reflects a significant gut metabolic activity ${ }^{(6)}$. Sources of upper-tract endogenous secretions are: saliva (mouth), gastric secretions (stomach), secretion of bile (duodenum), pancreatic secretions (duodenum) and mucins (upper tract). In addition, considerable quantities of epithelial cells are sloughed off into the lumen and plasma proteins (e.g. serum albumin, immunoglobulins), enzymes and various sources of non-protein nitrogen enter the gut lumen. Although 'non-dietary' rather than 'endogenous', microbial protein, which makes up a considerable proportion of the proteinaceous material in the digesta ${ }^{(7)}$, is often included as part of the endogenous protein measure.

Estimates of the amounts of the various materials entering the human gut are highly variable, but it would appear that some 90 grams of endogenous protein per day flows through the digestive tract from the mouth to the terminal ileum in the adult human ${ }^{(8)}$. Much of this endogenous protein is reabsorbed before the end of the small intestine, with net endogenous protein loss being determined at the terminal ileum. The total amount of nitrogenous material entering the gut lumen is influenced by various dietary factors. It has been known for many years, for example, that the gut enzymatic secretions are influenced by both the amount and type of protein ${ }^{(9,10)}$. Plant non starch polysaccharides and potentially, resistant starch can greatly influence the loss of endogenous protein at the end of the ileum ${ }^{(11,12)}$. As well as having an abrasive effect on the gut wall, plant fibres, because of their absorptive, water-holding, adsorptive and gel forming properties may trap endogenous proteins within their structures, thus enhancing the endogenous loss.

A large number of plant-based anti-nutritional factors, such as tannins, lectins and trypsin inhibitors, present in food raw material and sometimes still partially active in processed and cooked foods, are well documented as influencing the digestion of protein and leading to greater ileal losses of endogenous proteins ${ }^{(13)}$. At least in growing animals, it is considered that the endogenous protein flow at the end of the ileum is related to food dry-matter intake (and perhaps more appropriately the undigested dry-matter residue) and bodyweight ${ }^{(14,13)}$ and may also be influenced by dietary protein content ${ }^{(15,16)}$. There is no evidence that ileal endogenous protein loss is affected by the amino acid composition of the protein.

The net loss of endogenous amino acids at the end of the ileum is the result of total secretion, breakdown and reabsorption with subsequent re-utilisation of the reabsorbed amino acids. Several measures of the apparent reabsorption of gut endogenous protein have been made with estimates ranging from $60 \%-80 \%{ }^{(17,18,19,20,21,22)}$. The amount of endogenous protein flowing past the terminal ileum is probably around 20 to $30 \%$ of total secretions. Based on an $80 \%$ rate of reabsorption and an endogenous protein flow of $90 \mathrm{~g}$ protein/ day (FAO, WHO, UNU, 2007) ${ }^{(8)}$, a loss of protein from the small bowel of $18 \mathrm{~g}$ protein/day can be calculated. This figure is not inconsistent with recent direct empirical determinations of ileal endogenous protein loss in humans.
It can be concluded that the loss of amino acids and nitrogen from the upper digestive tract into the large bowel is quantitatively significant. The loss of amino acids, which is usually a permanent loss to the animal, represents a considerable metabolic drain on amino acid supply and has implications for the assessment of amino acid requirements for humans ${ }^{(23,24)}$. The ileal amino acid losses, furthermore, have profound implications for the determination of dietary amino acid digestibility. Determined amino acid digestibility should be a measure of the ingested amino acids (i.e. dietary amino acids) corrected for any undigested dietary amino acids, and thus the endogenous amino acids present in the ileal digesta need to be quantified and corrected for. If no correction is made for the endogenous amino acids present in ileal digesta, a coefficient of digestibility termed "apparent" digestibility is obtained. When correction for the endogenous component is made, the coefficient is termed "true". True amino acid digestibility is an intrinsic characteristic of the food, while apparent digestibility is highly influenced by digestibility assay conditions. At a set food dry-matter intake, whereby the ileal endogenous flow may be constant, the determined apparent amino acid digestibility coefficient increases markedly and curvilinearly from low to higher dietary amino acid contents ${ }^{(25)}$. This is an artefact of the assay, and reflects a disproportionate influence of the uncorrected-for ileal endogenous amino acid flow, at the lower amino acid intakes.

\section{Methods for Determining Endogenous Ileal Amino Acids}

Traditionally endogenous ileal amino acids and protein have been determined after feeding the human subject or animal (model for human) a protein-free diet. This method has been criticised, however, as being unphysiological ${ }^{(26)}$, likely leading to underestimates of the endogenous losses pertaining to the protein-fed state ${ }^{(27)}$. For the amino acid proline seemingly abnormally high excretions have been noted associated with feeding animals a protein-free $\operatorname{diet}^{(28)}$ which may be explained by an altered gut metabolism due to the protein-free state ${ }^{(29)}$

Another traditional approach to determining gut endogenous amino acid losses, but under conditions of proteinalimentation, is the regression method. Here the subject or animal is fed increasing amounts of dietary protein (at a constant food dry matter intake) and endogenous loss is estimated by extrapolation. This method is cumbersome and makes assumptions concerning the shape of the response, and relies on mathematical extrapolation which can lead to high standard errors of estimation. The regression technique tends to give rise to similar values to the protein-free method ${ }^{(30)}$ and thus may also underestimate endogenous ileal amino acid flow.

At least three studies have been reported whereby proteinfree diets have been fed to adult human ileostomates and nitrogen passing the terminal ileum has been determined. The determined endogenous nitrogen flows were in close agreement, with an overall mean value of $800 \mathrm{mg}$ $\mathrm{N} / \mathrm{d}^{(31,32,33)}$ (range 719 to $845 \mathrm{mg} \mathrm{N} / \mathrm{d}$ ). There was also reasonably good agreement across the three studies for the 
endogenous losses of individual amino acids, and the overall mean endogenous ileal amino acid flows are given in Table 1.

Several methodologies have been developed to allow the determination of ileal endogenous amino acid flows under conditions of protein feeding, and these have been the subject of extensive review ${ }^{(27)}$. Of the methods available, two can be used with human subjects, namely the enzyme hydrolysed protein method (sometimes referred to as the peptide alimentation method), and the isotope dilution method. Stable isotopes (usually $15 \mathrm{~N}$ ) may be used to mark amino acids either in the diet or body, and thus allow the endogenous amino acid component of the digesta to be distinguished. For human studies it has been more common and convenient to label the food source ${ }^{(34)}$, but labelling of the food source is not always straightforward logistically.

For this reason and also because labelled amino acids recycle rapidly in the gut leading to some degree of underestimation of endogenous amino acid loss with this $\operatorname{method}^{(27)}$, the use of isotope dilution is more suited to experimental investigations rather than routine dietary evaluation. A method that may have more promise for routine application, called the enzyme hydrolysed protein method, was first proposed by Moughan et $a l .{ }^{(35)}$. The enzyme hydrolysed protein method allows endogenous ileal amino acid flows to be determined in subjects fed a semi-synthetic corn starch based diet containing a hydrolysed protein (small peptides and free amino acids) as the sole source of dietary nitrogen. Commonly enzyme hydrolysed casein (MW < $5000 \mathrm{Da}$ ) has been used, but the hydrolysate of any purified protein is suitable. The mixture of free amino acids and oligo-peptides is prepared so as to simulate the product of gastric digestion. Digesta are collected from the terminal ileum of the subject or animal given the hydrolysed protein, and are first centrifuged and then ultrafiltered, removing materials with molecular weights lower than the filtration cutoff (usually 10,000 Da though lower MW cut-offs can be applied). This step removes any undigested dietary peptides

Table 1. Overall meant endogenous ileal amino acid losses determined in adult human ileostomates given a protein-free diet

\begin{tabular}{lcc}
\hline & \multicolumn{2}{c}{ Amino acid flow } \\
\cline { 2 - 3 } & $\mathrm{mg} / \mathrm{d}$ & Relative to lysine $=100$ \\
\hline Lysine & 203 & 100 \\
Methionine & 39 & 19 \\
Cysteine & 144 & 71 \\
Threonine & 297 & 146 \\
Valine & 227 & 112 \\
Isoleucine & 126 & 62 \\
Leucine & 240 & 118 \\
Phenylalanine & 146 & 72 \\
Tyrosine & 138 & 68 \\
Histidine & 125 & 62 \\
Serine & 233 & 115 \\
Glutamic acid & 362 & 178 \\
Alanine & 167 & 82 \\
Proline & 282 & 139 \\
Arginine & 179 & 88 \\
Aspartic acid & 348 & 171 \\
& & \\
\hline
\end{tabular}

†Overall mean of mean values from each of three studies ${ }^{(31,32,33)}$ and free amino acids. The high molecular weight fraction (the retentate, $>10,000 \mathrm{Da}$ ) contains the endogenous protein. An advantage of the enzyme hydrolysed protein method is that it allows a direct determination of the endogenous losses of all of the amino acids.

With the enzyme hydrolysed protein method, however, there will be some loss of small peptides and free amino acids (especially glycine conjugated to bile salts) of endogenous origin in the discarded ultrafiltrate, but for most of the amino acids such loss is likely of small magnitude. Indeed, it has been queried by some as to whether the method may actually lead to an overestimation of endogenous amino acid losses, due to the action of potentially unrepresentative amounts of bioactive peptides in the hydrolysate. Recent findings, however, from a study designed to evaluate the latter hypothesis ${ }^{(36)}$, suggest that such concerns are unfounded, but the potential for specific physiological effects of the peptides should be considered when using the enzyme hydrolysed protein method for quantifying endogenous gut protein losses.

The enzyme hydrolysed protein method allows the determination of endogenous nitrogen and amino acid flows associated with the ingestion of nitrogen-containing dry matter (basal flows; food dry matter intake associated), under a dietary condition that would seem to be more acceptable physiologically than use of a protein-free diet.

The presence in the diet of antinutritional factors (ANF's) and non-starch-polysaccharides (NSP's) can lead to endogenous amino acid excretions greater than the basal level determined with the enzyme hydrolysed protein method. The effects of these factors cannot be determined readily using the latter method.

\section{Physiologically-relevant estimates of endogenous ileal nitrogen and amino acid flow in humans}

Both the enzyme hydrolysed protein and isotope dilution methods have been applied with adult humans. Moughan et $a l{ }^{(33)}$ fed enzyme hydrolysed casein to adult ileostomates and after ultrafiltration of the ileal digesta determined an endogenous total nitrogen flow of around $1700 \mathrm{mg} \mathrm{N} / \mathrm{d}$. This agrees well with an estimate $(1850 \mathrm{mg} \mathrm{N} / \mathrm{d}$ ) based on $15 \mathrm{~N}$ isotope dilution in naso-ileo intubated adults given labelled hydrolysed casein ${ }^{(37)}$. Two other relevant published estimates of endogenous ileal total nitrogen flow are $1638 \mathrm{mg} \mathrm{N} / \mathrm{d}$ (isotope dilution, $15 \mathrm{~N}$ milk protein) $)^{(23)}$ and $2184 \mathrm{mg} \mathrm{N} / \mathrm{d}$ (isotope dilution, $15 \mathrm{~N}$ casein) ${ }^{(37)}$, giving an overall mean value (across four studies) of $1852 \mathrm{mg} \mathrm{N} / \mathrm{d}$. This value is substantially higher than the best estimate for the protein-free diet method discussed above $(800 \mathrm{mg} \mathrm{N} / \mathrm{d}$ ). This result mirrors what is found with other simple-stomached mammals, that there is a major effect of dietary protein on endogenous ileal total nitrogen flow. Two of the above discussed studies ${ }^{(23,33)}$ have also given values for endogenous ileal amino acid flows determined under peptide/protein alimentation. The overall mean endogenous ileal amino acid flows are given in Table 2. Once again, the endogenous ileal flows for the individual amino acids tended to be higher than their 
Table 2. Overall mean endogenous ileal amino acid losses determined in adult humans given peptide- or protein-containing diets

\begin{tabular}{lcc}
\hline & \multicolumn{2}{c}{ Amino acid flow } \\
\cline { 2 - 3 } & $\mathrm{mg} / \mathrm{d}+1$ & Relative to lysine $=100 \ddagger 2$ \\
\hline Lysine & 270 & 100 \\
Methionine & 110 & 41 \\
Cysteine & 150 & 56 \\
Threonine & 393 & 152 \\
Valine & 390 & 138 \\
Isoleucine & 233 & 99 \\
Leucine & 341 & 139 \\
Phenylalanine & 181 & 79 \\
Tyrosine & 180 & 89 \\
Histidine & 185 & 83 \\
Serine & 363 & 142 \\
Glutamic acid & 981 & 287 \\
Alanine & 272 & 101 \\
Proline & 507 & 160 \\
Arginine & 196 & 73 \\
Aspartic acid & 725 & 258 \\
& & \\
& &
\end{tabular}

protein-free counterparts (Table 1). When, however, the ileal amino acid losses were expressed relative to lysine at 100 units (Tables $1 \& 2$ ) the relative amino acid compositions of the two types of digesta were more similar though some considerable differences still persisted for some amino acids. It is also interesting to note, in this comparison across studies, that there was no evidence found for an 'abnormally' high ileal endogenous flow of proline with a protein-free versus protein dietary regimen.

\section{Relevance of correcting for endogenous ileal amino acid losses in determining dietary amino acid digestibility}

Ileal endogenous amino acid loss can be considered to be made up of two parts: a loss of amino acids associated with the flow through the upper digestive tract of protein-containing food dry-matter per se, called the basal amino acid loss (food dry-matter associated intake; determined at a defined protein intake) and a part over and above the basal loss specific to the nature of the protein source itself (specific loss, i.e. ingredient-associated and reflecting the effects of ANF's, plant fibre etc). A purified animal protein, such as casein for example, would not elicit any specific losses and the endogenous ileal amino acid flow would be the basal loss.

When the total ileal amino acid flow is not corrected for endogenous amino acid flow (either basal or specific loss), 'apparent' coefficients of digestibility are obtained. As discussed above, apparent coefficients of digestibility are affected by external assay conditions which gives rise to variability and leaves the apparent digestibility assay open to error. When the total ileal amino acid flow is corrected for the basal endogenous losses, 'true' amino acid digestibility is obtained. True amino acid digestibility is a fundamental property of the protein source, and is not affected by the assay conditions (e.g. feeding level, dietary amino acid concentration). Some plant foods which contain fibre and ANF's may stimulate increased endogenous ileal amino acid losses, above the basal level. If these increased losses (specific losses) are taken into account in determining digestibility, coefficients that have been termed 'real' digestibility are obtained. For protein sources that do not contain plant fibre or ANF's 'true' and 'real' amino acid digestibility coefficients will be numerically the same. For foods containing fibre and/or ANF's, only 'real' digestibility coefficients (i.e. corrected for basal plus specific losses) will provide an accurate assessment of amino acid absorption, and 'true' digestibility coefficients will underestimate the actual extent of dietary amino acid uptake.

There is some confusion concerning the terminology used to define protein digestibility with the term 'true' digestibility being used in slightly different ways by different scientists. In the present discussion, true amino acid digestibility is defined as apparent amino acid digestibility corrected for the basal amino acid losses determined after feeding either a protein-free or protein-containing diet. The protein-free diet approach to determining endogenous amino acids is considered unphysiological and basal losses should be determined at a set food dry-matter and protein intake. Sometimes (see Columbus and deLange; Fuller, this supplement) the term 'true' digestibility is used to mean 'real' digestibility. Increasingly, the term 'standardised' is being used instead of the term 'true', where basal loss is determined using an agreed upon protein-free estimate of endogenous amino acid loss and the term 'real' is becoming out-moded.

When choosing the type of digestibility coefficient to be used in dietary evaluation, consideration needs to be given as to how amino acid requirements have been assessed and presented for use, to ensure a compatibility of expression. Also, cognisance needs to be given to the methods available for determining the specific endogenous amino acid losses, which for humans are not routine. Taking both these factors into consideration, true ileal amino acid digestibility coefficients would seem to be the method of choice for application in human nutrition. For foods that do support a specific endogenous amino acid loss, over and above the basal loss, the specific loss is costed against the protein source itself, resulting in a lowered digestibility coefficient in comparison to the comparable 'real' digestibility value. This is appropriate, as the extra specific amino acid loss (a cost to the body) will likely not be reflected in estimates of the amino acid requirement, as high-quality dietary proteins (not containing non starch polysaccharides and anti nutritional factors) are usually used in studies to determine amino acid requirements in humans.

Either the protein-free method or the enzyme hydrolysed protein method may be used to routinely determine the basal endogenous ileal amino acid losses in humans and animals as models for humans. The enzyme hydrolysed protein method, where the gut tissues receive dietary amino acids, however, perhaps is more acceptable from a physiological perspective. Also, protein-free diets are unpalatable and being nutritionally unbalanced should only be fed to animals for short periods of time. Enzyme-hydrolysed protein based 
diets, on the other hand, are readily eaten by animals with accompanying normal growth and positive body nitrogen balance. Although the amount of dietary protein may influence endogenous ileal amino acid loss there is little evidence for any effect of the type of refined protein (i.e. proteins not containing fibre or ANF's), so flows obtained after feeding enzyme hydrolysed protein should be general.

\section{A proposed procedure for determining true ileal amino acid digestibility with application to humans}

If the true ileal digestibility of amino acids in foods for humans is to be determined routinely, an animal model must be adopted. The naso-gastric intubation method can be used with human subjects to sample ileal digesta, but the method is far from routine and requires an acute feeding and sampling procedure, and is restricted to refined finely-ground protein sources usually given as liquids. The cooperation of ileostomates has been relied upon in past studies, but this approach also is not routine and there is evidence that the human ileostomate may be an unsatisfactory model for the normal human. The pig being a meal eating omnivore with a simple digestive system has been shown to be a good model for nutrient digestion in the human and particularly so for protein digestion ${ }^{(38,39,40,41)}$. Ileal digesta can be readily sampled from conscious pigs via a T-piece ileal cannula or through a postvalvular T caecum cannula (PVTC) inserted in the caecum immediately adjacent to the ileo-caecal valve. Such surgical methods are well perfected. The cannulated pig is a better model for use in determining ileal amino acid digestibility for humans than the laboratory rat, both logistically (meal feeding with pig and greater digesta sample size, repeat measures etc) and in terms of digestive physiological similarities.

It is proposed that the $30-50 \mathrm{~kg}$ live weight cannulated pig be used as a model to allow routine evaluation of protein foods for humans. Direct controlled comparisons of true ileal amino acid digestibility in pigs and humans suggest that amino acid digestibility may be different between the species to a small degree, but regression equations have been published $^{(41)}$ which allow prediction of true ileal amino acid digestibility values for humans based on pig digestibility data. Cannulated pigs would be given the test protein included (10-12\% of test diet) in a semi-synthetic corn-starch based diet, also including corn oil, a vitamin/mineral premix and a small amount (5\%) of purified wood cellulose. The latter material is added to maintain regular defaecation in the animal and has little influence on endogenous protein loss ${ }^{(42)}$. The same semi-synthetic diet would be fed to allow determination of the endogenous ileal amino acid flows (with ultrafiltration of the digesta), except that the protein source would be replaced iso-nitrogenously with enzymehydrolysed casein $(<5000 \mathrm{Da})$. Each pig would be used as its own control for the determination of the endogenous amino acid loss in a replicated cross-over design, thus removing the influence of potential effectors such as genotype, bodyweight, feeding level and dietary protein content. True amino acid digestibility coefficients would be determined after correction for the basal endogenous amino acid loss, and the equivalent human true ileal amino acid digestibility values predicted based on published regression relationships.

\section{Conclusion}

Amino acid digestibility may vary considerably across diverse dietary protein sources. It is thus important that amino acid digestibility be determined accurately, such that measures of dietary protein quality such as PDCAAS (protein digestibility corrected amino acid score) and other measures can be calculated meaningfully. Currently, faecal total nitrogen digestibility determined in the rat is used in the calculation of PDCAAS values. From a theoretical stance, this is not good practice. The rat is not the best animal model for humans in determining protein digestibility and faecal total nitrogen digestibility is likely to overestimate the more appropriate ileal digestibility value. Further, digestibilities for the individual amino acids can vary greatly from the digestibility of crude protein.

The argument put forward here is that the true ileal amino acid digestibility assay is inherently superior to assays used currently, and a practical procedure for determining amino acid digestibility using the pig as an animal model has been suggested which with some refinement could become a standard method. Such an assay has the potential to generate accurate data on amino acid and protein digestibility in ingredients and foods, with application in allowing accurate dietary assessment and planning.

\section{Acknowledgements}

The authors have no conflict of interest to declare. PM wrote the paper with contributions from SR. This research received no specific grant from any funding agency in the public, commercial or not-for-profit sectors.

\section{References}

1. Moughan PJ \& Stevens BR (2012) Digestion and absorption of protein. In Biochemical, Physiological and Molecular Aspects of Human Nutrition, pp 162-178 [MH Stipanuk and MA Caudill, editors]. St Louis, USA: Elsevier.

2. Rowan AM (1989) A study of the digestion of protein in humans using ileal and faecal assays. MSc Thesis, Massey University

3. Moughan PJ \& Smith WC (1985) Determination and assessment of apparent ileal amino acid digestibility coefficients for the growing pig. NZ J of Agric Res 28, 365-370.

4. Moughan PJ (2003) Amino acid availability; aspects of chemical analysis and bioassay methodology. Nutr Res Rev 16, 127-141.

5. Columbus D \& de Lange CFM (2012) Evidence for validity of ileal digestibility coefficients in monogastrics. $\mathrm{Br} J \mathrm{Nutr}$ 108(Suppl 2), S264-S272.

6. Lobley GE (2003) Protein turnover - what does it mean for animal production? Can J Anim Sci 83, 327-340.

7. Miner-Williams W, Moughan PJ \& Fuller MF (2009) Endogenous components of digesta protein from the terminal ileum of pigs fed a casein-based diet. J Agric Food Chem 57, 2072-2078.

8. FAO, WHO, UNU (2007) Protein and amino acid requirements in human nutrition. Report of a joint FAO/WHO/UNU 
expert consultation (WHO Technical Report Series No. 935). Geneva: World Health Organisation.

9. Zebrowska H, Simon O, Münchmeyer R, et al. (1982) Investigations on the animo acid secretion and absorption in the stomach of the growing pig. Arch Anim Nutr 32, 703-710.

10. Simon O, Zebrowska T, Bergner H, et al. (1983) Investigations on the pancreatic and stomach secretion in pigs by means of continuous infusion of ${ }^{14} \mathrm{C}$-amino acids. Arch Anim Nutr 33, 9-22.

11. Rérat A (1991) Carbohydrate interactions on protein and amino acid digestibility and absorption and metabolic consequences in the pig. In Proc $6^{\text {th }}$ Int Symp Protein Metabolism and Nutrition, pp. 1-37 [BO Eggum, S Boisen, C Borsting, A Danfaer and T Hvelplund, editors]. Foulum, Denmark: National Institute of Animal Science.

12. Schulze H. (1994) Endogenous ileal nitrogen losses in pigs Dietary factors. PhD Thesis, Wageningen Agricultural University.

13. Nyachoti CM, de Lange CFM, McBride BW, et al. (1997) Significance of endogenous gut nitrogen losses in the nutrition of growing pigs: A review. Can J Anim Sci 77, 149-163.

14. Butts CA, Moughan PJ, Smith WC, et al. (1993) The effect of food dry matter intake on endogenous ileal amino acid excretion determined under peptide alimentation in the $50 \mathrm{~kg}$ liveweight pig. J Sci Food Agric 62, 235-243.

15. Hodgkinson SM, Moughan PJ, Reynolds GW, et al. (2000) The effect of dietary peptide concentration on endogenous ileal amino acid loss in the growing pig. Br J Nutr $\mathbf{8 3}$, 421-430.

16. Hodgkinson SM \& Moughan PJ (2007) An effect of dietary protein content on endogenous ileal lysine flow in the growing rat. J Sci Food Agric 87, 233-238.

17. Krawielitzki KT, Zebrowska T, Schadereit R, et al. (1990) Determining of nitrogen absorption and nitrogen secretion in different sections of the pig's intestine by digesta exchange between $15 \mathrm{~N}$ labelled and unlabelled animals. Arch Anim Nutr 40, 25-27.

18. Souffrant WB. (1991) Endogenous nitrogen losses during digestion in pigs. In Digestive Physiology in Pigs, pp. 147 [MWA Verstegen, J Huisman and LA den Hartog, editors]. Wageningen (Doorwerth), PUDOC, Wageningen

19. Voigt J, van Bruchem J, Lammers-Wienhoven T, et al. (1994) Flow of endogenous protein along the small intestine of sheep. Effect of cell walls. In Proc Soc Nutr Physiol, vol. 3, pp. 104

20. Krawielitzki K, Kreienbring F, Zebrowska T, et al. (1994) Estimation of $\mathrm{N}$ absorption, secretion, and reabsorption in different intestinal sections of growing pigs using the $15 \mathrm{~N}$ isotope dilution method. In $6^{\text {th }}$ International Symposium on Digestive Physiology in Pigs, vol. 1, pp. 79-82 [WB Souffrant and H Hagemeister, editors]. 4-6 October 1994, Bad Doberan, Germany.

21. Souffrant WB, Darcy-Vrillon B, Corring T, et al. (1986) Recycling of endogenous nitrogen in the pig (preliminary results of a collaborative study). Arch Anim Nutr 36, 269-274.

22. Souffrant WB, Rérat A, Laplace JP, et al. (1993) Exogenous and endogenous contributions to nitrogen fluxes in the digestive tract of pigs fed a casein diet. III. Recycling of endogenous nitrogen. Reprod Nutr Dev 33, 373-382.

23. Gaudichon C, Bos C, Morens C, et al. (2002) Ileal losses of nitrogen and amino acids in humans and their importance to the assessment of amino acid requirements. Gastroenterology 123, 50-59.

24. Moughan PJ (2005) Physiological processes underlying the dietary amino acid requirement in humans. The role of the gut. In Proceedings of the $18^{\text {th }}$ International Congress of
Nutrition, Durban, South Africa, pp. 10 [HH Vorster R Blaauw, MA Dhansay, PMN Kuzwayo, L Moeng and E Wentzel-Viljoen, editors]., ISBN 3-8055-8015-0.

25. Donkoh A \& Moughan PJ (1994) The effect of dietary crude protein content on apparent and true ileal nitrogen and amino acid digestibilities. Br J Nutr 72, 59-68.

26. Low AG (1980) Nutrient absorption in pigs. J Sci Food Agric 31, 1087-1300.

27. Moughan PJ, Souffrant WB \& Hodgkinson SM (1998) Physiological approaches to determining gut endogenous amino acid flows in the mammal. Arch Anim Nutr 51, 237-252.

28. Skilton GA, Moughan PJ \& Smith WC (1988) Determination of endogenous amino acid flow at the terminal ileum of the rat. J Sci Food Agric 44, 227-235.

29. Sauer WC \& de Lange CFM (1992) Novel methods for determining protein and amino acid digestibilities in feedstuffs In Modern Methods in Protein Nutrition and Metabolism, pp. 87-119 [S Nissen, editor]. New York: Academic Press.

30. Donkoh A, Moughan PJ \& Morel PCH (1995) Comparison of methods to determine the endogenous amino acid flow at the terminal ileum of the growing rat. J Sci Food Agric 67, 359-366.

31. Rowan AM, Moughan PJ \& Wilson MN (1993) Endogenous amino acid flow at the terminal ileum of adult humans determined following the ingestion of a single protein-free meal J Sci Food Agric 61, 439-442.

32. Fuller M, Milne A, Harris CI, et al. (1994) Amino acid losses in ileostomy fluid on a protein-free diet. Am J Clin Nutr $\mathbf{5 9}$ $70-73$.

33. Moughan PJ, Butts CA, Rowan AM, et al. (2005) Dietary peptides increase gut endogenous amino acid losses in adult humans. Am J Clin Nutr 81, 1359-1365.

34. Mahé S, Fauquant J, Gaudichon C, et al. (1994) 15N-labelling and preparation of milk, casein and whey proteins. Lait $\mathbf{7 4}$ 307-312.

35. Moughan PJ, Darragh AJ, Smith WC, et al. (1990) Perchloric and trichloroacetic acids as precipitants of protein in endogenous ileal digesta from the rat. J Sci Food Agric 52, $13-21$.

36. Deglaire A, Moughan PJ, Bos C, et al. (2008) A casein hydrolysate does not enhance gut endogenous protein flows compared with intact casein when fed to growing rats. $J$ Nutr 138, 556-561.

37. Deglaire A. (2008) Gut endogenous protein flows and postprandial metabolic utilization of dietary amino acids in simple-stomached animals and humans. PhD Thesis, Massey University, Palmerston North, New Zealand.

38. Moughan PJ, Birtles MJ, Cranwell PD, et al. (1992) The piglet as a model animal for studying aspects of digestion and absorption in milk-fed human infants. World Rev Nutr Diet 67, 40-113.

39. Moughan PJ, Cranwell PD, Darragh AJ, et al. (1994) The domestic pig as a model for studying digestion in humans In Digestive Physiology in the pig, vol II, pp. 389-396 [WB Souffrant and H Hagemeister, editors]., Forschungsinstitut fur die Biologie Landwirtschaftlicher Nutztiere (FBN)

40. Rowan AM, Moughan PJ, Wilson MN, et al. (1994) Comparison of the ileal and faecal digestibility of dietary amino acids in adult humans and evaluation of the pig as a model animal for digestion studies in man. Br J Nutr 71, 29-42.

41. Deglaire A, Bos C, Tomé D, et al. (2009) Ileal digestibility of dietary protein in the growing pig and adult human. BrJ Nutr 102, 1752-1759.

42. Boisen S \& Moughan PJ (1996) Dietary influences on endogenous ileal protein and amino acid loss in the pig - A Review. Acta Agric Scand 46, 154-164. 